\title{
Cryobacterium psychrotolerans sp. nov., a novel psychrotolerant bacterium isolated from the China No. 1 glacier
}

\author{
De-Chao Zhang, ${ }^{1,2}$ He-Xiang Wang, ${ }^{2}$ Heng-Lin Cui, ${ }^{1}$ Yong Yang, ${ }^{1}$ \\ Hong-Can Liu, ${ }^{1}$ Xiu-Zhu Dong ${ }^{1}$ and Pei-Jin Zhou ${ }^{1}$ \\ ${ }^{1}$ State Key Laboratory of Microbial Resources, Institute of Microbiology, Chinese Academy of \\ Sciences, Beijing 100080, People's Republic of China \\ ${ }^{2}$ State Key Laboratory for Agrobiotechnology, College of Biological Sciences, China Agricultural \\ University, Beijing 100094, People's Republic of China
}

Correspondence

Pei-Jin Zhou

zhou@sun.im.ac.cn
The genus Cryobacterium was described by Suzuki et al. (1997) as including Gram-positive, aerobic, obligately psychrophilic bacteria that had a pleomorphic rod-shaped morphology. To date, the genus Cryobacterium comprises only one species, Cryobacterium psychrophilum, which was isolated from Antarctic soil (Inoue, 1976) and named 'Curtobacterium psychrophilum' (Inoue et al., 1976) until amended and renamed as Cryobacterium psychrophilum by Suzuki et al. (1997).

The China No.1 glacier, located in Xinjiang Uygur Autonomous Region, north-west China, is a relatively simple and closed ecosystem. Three psychrophiles were isolated from the area during our survey of cold-adapted micro-organisms (Zhu et al., 2003; Zhang et al., 2006). In this study, we report the isolation and identification of strain $0549^{\mathrm{T}}$. Physiological, biochemical, chemotaxonomic characterization and a phylogenetic analysis (based on $16 \mathrm{~S}$ rRNA gene sequences) indicated that the new isolate could represent a novel species of the genus Cryobacterium.

The GenBank/EMBL/DDBJ accession number for the 16S rRNA gene sequence of strain $0549^{\top}$ is DO515963.

The fatty acid profiles of strain $0549^{\top}$ and Cryobacterium psychrophilum JCM $1463^{\top}$ are available in a supplementary table in IJSEM Online.
Strain $0549^{\mathrm{T}}$ was isolated from frozen soil collected from the China No. 1 glacier using previously described media and methods (Zhu et al., 2003). The strain was obtained in pure culture after three successive transfers to fresh agar medium and was stored at $-80{ }^{\circ} \mathrm{C}$ in $30 \%(\mathrm{v} / \mathrm{v})$ glycerol. Strain $0549^{\mathrm{T}}$ was routinely grown aerobically at $20^{\circ} \mathrm{C}$ in PYG medium, which comprised $\left(1^{-1}\right): 5 \mathrm{~g}$ Bacto peptone (Difco), $0.2 \mathrm{~g}$ yeast extract (Oxoid), $5 \mathrm{~g}$ glucose, $3 \mathrm{~g}$ beef extract (Oxoid), $0.5 \mathrm{~g} \mathrm{NaCl}$ and $1.5 \mathrm{~g} \mathrm{MgSO}_{4} \cdot 7 \mathrm{H}_{2} \mathrm{O}$ (pH adjusted to 7.0 ). Cryobacterium psychrophilum JCM $1463^{\mathrm{T}}$ was obtained from the Japan Collection of Microorganisms (Saitama, Japan) and was used as a reference strain. This culture was grown using medium containing $\left(\mathrm{l}^{-1}\right): 10 \mathrm{~g}$ Bacto peptone (Difco), $5 \mathrm{~g}$ yeast extract, $5 \mathrm{~g}$ Casamino acids (Difco), $2 \mathrm{~g}$ meat extract (Difco), $5 \mathrm{~g}$ malt extract (Difco), $2 \mathrm{~g}$ glycerol, $1 \mathrm{~g}$ $\mathrm{MgSO}_{4} .7 \mathrm{H}_{2} \mathrm{O}$ and $0.05 \mathrm{~g}$ Tween 80 (pH adjusted to 7.2).

DNA was extracted and purified as described by Sambrook et al. (1989). The $16 \mathrm{~S}$ rRNA gene was amplified by a PCR with the forward primer 5'-AGAGTTTGATCCTGGCTCAG-3' and the reverse primer 5'-AAGGAGGTGATCCAGCCGCA-3' (Liu et al., 2000). The PCR product was sequenced by using the $\mathrm{ABI}$ BigDye 3.1 sequencing kit (Applied Biosystems) and an automated DNA sequencer (model ABI3730; Applied Biosystems). The 16S rRNA gene sequence of strain $0549^{\mathrm{T}}$ (1399 bp) was submitted to 
GenBank and EMBL to search for similar sequences by using the BLAST algorithm. Phylogenetic trees were constructed using the neighbour-joining (Saitou \& Nei, 1987) and maximum-parsimony algorithms with Kimura's twoparameter model (Kimura, 1980) implemented in MEGA, version 3.0 (Kumar et al., 2004). The resulting tree topologies were evaluated with a bootstrap analysis based on 1000 replicates. A phylogenetic analysis (Fig. 1) based on a consensus $1166 \mathrm{bp}$ length of $16 \mathrm{~S}$ rRNA gene sequence showed that strain $0549^{\mathrm{T}}$ grouped as a member of the genus Cryobacterium, forming a distinct cluster with Cryobacterium psychrophilum JCM $1463^{\mathrm{T}}$ (96.5\%) with strong support (100\%).

Cell morphology was examined under a light microscope (BH-2; Olympus). The growth temperature was determined with a TN3F temperature-gradient incubator (Advantec). The $\mathrm{pH}$ range for growth was determined for the culture in PYG at various $\mathrm{pH}$ values obtained by adjustment with $\mathrm{HCl}$ or $\mathrm{NaOH}\left(1 \mathrm{~mol} \mathrm{l}^{-1}\right)$. The following tests were performed according to Dong \& Cai (2001): catalase and oxidase activities, Voges-Proskauer reaction, Simmons' citrate test, hydrolysis of DNA, starch, gelatin and casein, activities of lipase, arginine dihydrolase, lysine decarboxylase, ornithine decarboxylase, lecithinase and tryptophan deaminase, and the utilization of various substrates as sole carbon and energy sources. Acid production from carbohydrates was determined as described by Leifson (1963). The cells of strain $0549^{\mathrm{T}}$ were irregularly rod-shaped, Gram-positive and motile. Colonies on PYG agar were yellow, smooth and convex with entire margins.

Menaquinones were extracted and purified according to Collins (1985) and were analysed by using HPLC (Wu et al., 1989). The cellular polar lipids were extracted and analysed on silica-gel plates (Kieselgel 60 F; Merck) by using TLC (Kates, 1986). Cell-wall peptidoglycan was prepared by using a method described previously (Komagata \& Suzuki, 1987). Amino acid compositions were determined using an automatic amino acid analyser (model S 433D; Sykam) equipped with a separation column (LCA K06/Na). TLC determination of cell-wall sugar was performed as described previously (Lechevalier \& Lechevalier, 1970). Cellular fatty acids were determined from a culture grown in PYG at $20^{\circ} \mathrm{C}$ for 3 days and were extracted, methylated and analysed using the standard MIDI (Microbial Identification) system (Sasser, 1990). The major menaquinones found in strain $0549^{\mathrm{T}}$ included MK-12 (38\%), MK-11 (39\%) and MK-10

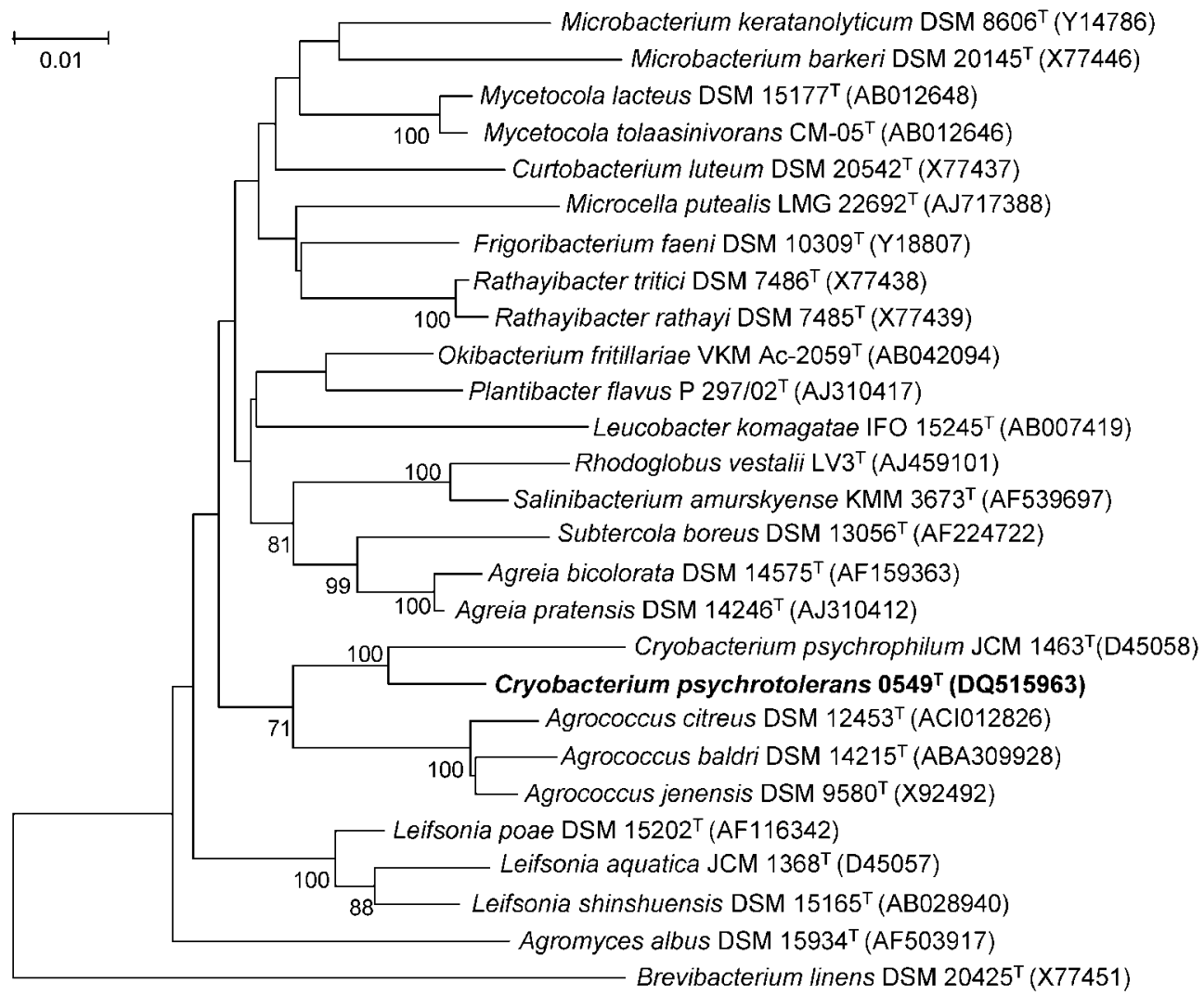

Fig. 1. Neighbour-joining phylogenetic dendrogram, based on $16 \mathrm{~S}$ rRNA gene sequence similarity, of strain $0549^{\top}$ and species of the family Microbacteriaceae. Brevibacterium linens DSM $20425^{\top}$ (X77451) served as an outgroup. Numbers at the nodes represent bootstrap support (\%) based on a neighbour-joining analysis of 1000 resampled datasets. GenBank accession numbers are given in parentheses. Bar, $1 \%$ sequence divergence. 
(16\%), followed by small amounts of MK-8 and MK-9. The main polar lipids present included diphosphatidylglycerol, phosphatidylglycerol and an unknown glycolipid. Cell-wall hydrolysates of strain $0549^{\mathrm{T}}$ contained 2,4-diaminobutyric acid as the diagnostic diamino acid; the molar ratio for glutamic acid/glycine/alanine/2,4-diaminobutyric acid was estimated to be $1.0: 0.9: 0.5: 1.1$. The main components of the whole-cell sugars were glucose and ribose. The predominant cellular fatty acids of strain $0549^{\mathrm{T}}$ were anteiso$\mathrm{C}_{15: 0}(39.7 \%)$, anteiso- $\mathrm{C}_{15: 1}(17.2 \%)$, iso- $\mathrm{C}_{15: 0}(11.8 \%)$, iso- $\mathrm{C}_{16: 0}(14.6 \%)$ and anteiso- $\mathrm{C}_{17: 0}(11.2 \%)$. The chemotaxonomic characteristics, such as the cell-wall peptidoglycan, the polar lipid profile and the fatty acid profile were in good agreement with those determined for Cryobacterium psychrophilum JCM $1463^{\mathrm{T}}$. In particular, both strains possessed very similar amounts of monounsaturated fatty acid (anteiso- $\mathrm{C}_{15: 1}$ ), which contributes to the maintenance of membrane fluidity at low temperatures (see the fatty acid profiles in Supplementary Table S1, available in IJSEM Online).

The $\mathrm{G}+\mathrm{C}$ content of the genomic DNA was determined by using the thermal denaturation method (Sly et al., 1986) with Escherichia coli $\mathrm{K}-12$ as the reference. DNA-DNA hybridization experiments were carried out by using the liquid renaturation method (De Ley et al., 1970) as modified by Huß et al. (1983). Both experiments were carried out using a DU800 spectrophotometer (Beckman). The DNA $\mathrm{G}+\mathrm{C}$ content of strain $0549^{\mathrm{T}}$ was $67 \mathrm{~mol} \%$. The DNADNA relatedness between strain $0549^{\mathrm{T}}$ and Cryobacterium psychrophilum JCM $1463^{\mathrm{T}}$ was $34 \%$.

Strain $0549^{\mathrm{T}}$ was distinguished from Cryobacterium psychrophilum by the following phenotypic and chemotaxonomic characteristics. Strain $0549^{\mathrm{T}}$ was psychrotolerant and grew at $4-27^{\circ} \mathrm{C}$, whereas Cryobacterium psychrophilum was obligately psychrophilic and grew optimally at $9-12{ }^{\circ} \mathrm{C}$, but not at $18^{\circ} \mathrm{C}$. The whole-cell sugars of Cryobacterium psychrophilum contained rhamnose and fucose, which were lacking in the cell wall of strain $0549^{\mathrm{T}}$. Cells of strain $0549^{\mathrm{T}}$ contained mainly MK-12, MK-11 and MK-10, whereas MK-10 was the major menaquinone in Cryobacterium psychrophilum. Other phenotypic features that can be used to differentiate strain $0549^{\mathrm{T}}$ from Cryobacterium psychrophilum are shown in the species description and Table 1. On the basis of these results, it is concluded that strain $0549^{\mathrm{T}}$ represents a novel species of the genus Cryobacterium, for which the name Cryobacterium psychrotolerans sp. nov. is proposed.

\section{Description of Cryobacterium psychrotolerans sp. nov.}

Cryobacterium psychrotolerans (psy.chro.tol'er.ans. Gr. adj. psychros cold; L. pres. part. tolerans tolerating; N.L. part. adj. psychrotolerans cold-tolerating).

Cells are Gram-positive, irregular rods, aerobic, psychrotolerant, motile and $0.5-0.8 \times 1.8-3.6 \mu \mathrm{m}$ in size. Colonies are
Table 1. Characteristics that differentiate strain $0549^{\top}$ from Cryobacterium psychrophilum

Taxa: 1, strain $0549^{\mathrm{T}} ; 2$, Cryobacterium psychrophilum (Suzuki et al., 1997). +, Positive; -, negative; $\mathrm{W}$, weakly positive.

\begin{tabular}{|c|c|c|}
\hline Characteristic & 1 & 2 \\
\hline Colony colour & Yellow & Pink \\
\hline Motility & + & - \\
\hline \multicolumn{3}{|l|}{ Growth temperature $\left({ }^{\circ} \mathrm{C}\right)$ : } \\
\hline Range & $4-27$ & $4-17$ \\
\hline Optimum & $20-22$ & $9-12$ \\
\hline \multicolumn{3}{|l|}{ Hydrolysis of: } \\
\hline Casein & + & - \\
\hline DNA & - & + \\
\hline Starch & + & $\mathrm{W}$ \\
\hline \multicolumn{3}{|l|}{ Acid from: } \\
\hline Arabinose & + & - \\
\hline Fructose & - & + \\
\hline Galactose & - & + \\
\hline Maltose & + & - \\
\hline Mannose & - & + \\
\hline Sucrose & - & + \\
\hline \multicolumn{3}{|l|}{ Assimilation of: } \\
\hline Fumarate & - & + \\
\hline Glutamate & + & - \\
\hline Hippurate & - & + \\
\hline Malate & - & + \\
\hline Pyruvate & - & + \\
\hline Nitrate reduction & + & - \\
\hline DNA G $+C$ content $(\mathrm{mol} \%)$ & 67 & 65 \\
\hline
\end{tabular}

yellow, smooth, circular and convex with entire margins. Catalase-positive and oxidase-negative. Growth occurs at $4-27^{\circ} \mathrm{C}$ and $\mathrm{pH} 5.0-10.0$, with optimum growth at $20-22^{\circ} \mathrm{C}$ and approximately $\mathrm{pH} 6.0-7.0$. Growth occurs in the presence of $0-4 \%(\mathrm{w} / \mathrm{v}) \mathrm{NaCl}$. Nitrate is reduced. Arginine dihydrolase, lysine decarboxylase, ornithine decarboxylase, lecithinase, urease, lipase and tryptophan deaminase activities are absent. The Simmons' citrate and Voges-Proskauer tests are negative. Hydrolyses casein, starch and aesculin, but not gelatin or DNA. The following substrates are utilized as sole carbon sources: glucose, maltose, sucrose, D-mannose, fructose, D-cellobiose, D-galactose, lactose, L-arabinose, xylose, glycerol, melezitose, ribose, salicin, inulin, glutamate, lactate, succinate and acetate. Acids are produced from glucose, arabinose, maltose and xylose. The following substrates are not utilized as sole carbon sources: mannitol, raffinose, L-rhamnose, D-sorbitol, sorbinose, galactitol, inositol, erythritol, gluconate, pyruvate, citrate, fumarate, hippurate, malate and tartrate. The major menaquinones are MK-11, MK-12 and MK-10. The main polar lipids are diphosphatidylglycerol, phosphatidylglycerol and an unknown glycolipid. The amino acids of the cell-wall peptidoglycan are 2,4-diaminobutyric acid, alanine, glycine and glutamic acid. The main components of the whole-cell sugars are glucose and ribose. 
The predominant cellular fatty acids are anteiso- $\mathrm{C}_{15: 0}$ (39.7\%), anteiso- $\mathrm{C}_{15: 1}(17.2 \%)$, iso- $\mathrm{C}_{15: 0}(11.8 \%)$, iso$\mathrm{C}_{16: 0}(14.6 \%)$, anteiso- $\mathrm{C}_{17: 0}(11.2 \%)$, iso- $\mathrm{C}_{14: 0}(1.7 \%)$, iso- $\mathrm{C}_{17: 0}(1.4 \%)$ and $\mathrm{C}_{16: 0}(0.9 \%)$. The genomic DNA $\mathrm{G}+\mathrm{C}$ content is $67 \mathrm{~mol} \%$.

The type strain, $0549^{\mathrm{T}}\left(=\right.$ CGMCC $\left.1.5382^{\mathrm{T}}=\mathrm{JCM} 13925^{\mathrm{T}}\right)$, was isolated from the China No. 1 glacier (Xinjiang Uygur Autonomous Region).

\section{Acknowledgements}

This work was supported by the National Basic Research Program of China (2004CB719601).

\section{References}

Collins, M. D. (1985). Isoprenoid quinone analysis in classification and identification. In Chemical Methods in Bacterial Systematics, pp. 267-287. Edited by M. Goodfellow \& D. E. Minnikin. London: Academic Press.

De Ley, J., Cattoir, H. \& Reynaerts, A. (1970). The quantitative measurement of DNA hybridization from renaturation rates. Eur J Biochem 12, 133-142.

Dong, X.-Z. \& Cai, M.-Y. (editors) (2001). Determination of biochemical properties. In Manual for the Systematic Identification of General Bacteria, pp. 370-398. Beijing: Science Press (in Chinese).

Huß, V. A. R., Festl, H. \& Schleifer, K.-H. (1983). Studies on the spectrophotometric determination of DNA hybridization from renaturation rates. Syst Appl Microbiol 4, 184-192.

Inoue, K. (1976). Quantitative ecology of microorganisms of Showa Station in Antarctica and isolation of psychrophiles. J Gen Appl Microbiol 22, 143-150.

Inoue, K. \& Komagata, K. (1976). Taxonomic study on obligately psychrophilic bacteria isolated from Antarctica. J Gen Appl Microbiol 22, 165-176.

Kates, M. (1986). Techniques of Lipidology, 2nd edn. Amsterdam: Elsevier.

Kimura, M. (1980). A simple method for estimating evolutionary rates of base substitutions through comparative studies of nucleotide sequences. J Mol Evol 16, 111-120.
Komagata, K. \& Suzuki, K. (1987). Lipid and cell wall analysis in bacterial systematics. Methods Microbiol 19, 161-207.

Kumar, S., Tamura, K. \& Nei, M. (2004). MEGA3: integrated software for molecular evolutionary genetics analysis and sequence alignment. Brief Bioinform 5, 150-163.

Lechevalier, M. P. \& Lechevalier, H. (1970). Chemical composition as a criterion in the classification of aerobic actinomycetes. Int J Syst Bacteriol 20, 435-443.

Leifson, E. (1963). Determination of carbohydrate metabolism of marine bacteria. J Bacteriol 85, 1183-1184.

Liu, H., Xu, Y., Ma, Y. \& Zhou, P. (2000). Characterization of Micrococcus antarcticus sp. nov., a psychrophilic bacterium from Antarctica. Int J Syst Evol Microbiol 50, 715-719.

Saitou, N. \& Nei, M. (1987). The neighbor-joining method: a new method for reconstructing phylogenetic trees. Mol Biol Evol 4, 406-425.

Sambrook, J., Fritsch, E. F. \& Maniatis, T. (1989). Molecular Cloning: a Laboratory Manual, 2nd edn. Cold Spring Harbor, NY: Cold Spring Harbor Laboratory.

Sasser, M. (1990). Identification of Bacteria by Gas Chromatography of Cellular Fatty Acids, MIDI Technical Note 101. Newark, DE: MIDI Inc.

Sly, L. I., Blackall, L. L., Kraat, P. C., Tian-Shen, T. \& Sangkhobol, V. (1986). The use of second derivative plots for the determination of mol\% guanine plus cytosine of DNA by the thermal denaturation method. J Microbiol Methods 5, 139-156.

Suzuki, K., Sasaki, J., Uramoto, M., Nakase, T. \& Komagata, K. (1997). Cryobacterium psychrophilum gen. nov., sp. nov., nom. rev., comb. nov., an obligately psychrophilic actinomycete to accommodate "Curtobacterium psychrophilum" Inoue and Komagata 1976. Int J Syst Bacteriol 47, 474-478.

Wu, C., Lu, X., Qin, M., Wang, Y. \& Ruan, J. (1989). Analysis of menaquinone compound in microbial cells by HPLC. Microbiology (English translation of Mikrobiologiia) 16, 176-178.

Zhang, D.-C., Wang, H.-X., Liu, H.-C., Dong, X.-Z. \& Zhou, P.-J. (2006). Flavobacterium glaciei sp. nov., a novel psychrophilic bacterium isolated from the China No. 1 glacier. Int J Syst Evol Microbiol 56, 2921-2925.

Zhu, F., Wang, S. \& Zhou, P. (2003). Flavobacterium xinjiangense sp. nov. and Flavobacterium omnivorum sp. nov., novel psychrophiles from the China No. 1. glacier. Int J Syst Evol Microbiol 53, 853-857. 